Dr Magdalena Parzyszek, https://orcid.org/0000-0002-8270-3388

Instytut Pedagogiki

Katolicki Uniwersytet Lubelski Jana Pawła II

\title{
Jak zrealizować wspólny projekt pt. „Małżeństwo”? \\ Papieża Franciszka koncepcja przygotowania do małżeństwa
}

\author{
How to implement the joint project known as marriage? \\ Pope Francis' conception of the preparation for marriage
}

https://doi.org/10.34766/fetr.v45i1.700

\begin{abstract}
Abstrakt: Papież Franciszek zwołując 5 października 2014 roku III nadzwyczajne zgromadzenie ogólne Synodu Biskupów nt. „Wyzwań duszpasterskich dla rodziny w kontekście nowej ewangelizacji”, oraz 24 października 2015 roku wydając dokument „Misja i powołanie rodziny w Kościele i w świecie wspótczesnym" zaprosił do refleksji m.in. nad przygotowaniem do małżeństwa. Dotyczy ona głoszenia kerygmatu i inicjacji w sakrament. Autorka artykułu podejmuje się odczytania rozumienia kerygmatu w nauczaniu papieża Franciszka rozumiejąc go jako orędzie mające moc przemiany życia, prowadzące do osobowej relacji z Bogiem, zawierające także konieczność proklamowania go w świecie.

Inicjację w sakrament rozumie jako „zakorzenienia przygotowania do małżeństwa w procesie inicjacji chrześcijańskiej, z zaakcentowaniem powiązania małżeństwa ze chrztem oraz innymi sakramentami" (Franciszek, 2016a, 206).

Refleksja nad wskazanymi treściami $\mathrm{w}$ związku $\mathrm{z}$ przygotowaniem do małżeństwa stanowi przyczynek do dyskusji nad zaproponowanym tematem.

Słowa kluczowe: inicjacja w sakrament, kerygmat, przygotowanie do małżeństwa

Abstract: Pope Francis convoking The Third Extraordinary General Assembly of the Synod of Bishops on 5th October 2014 on the topic of "Pastoral Challenges of the Family in the Context of Evangelization" and during The Fourteenth Ordinary General Assembly of the Synod of Bishops, popularly referred to as the Synod on the Family, releasing on 24 October 2015 the final report intitled "The Vocation and Mission of the Family in the Church and in the Contemporary World" invited to reflection on how to prepare for marriage. The author of this article undertakes to read the understanding of the kerygma in the teaching of Pope Francis, understanding it as a message with the power to transform lives, leading to a personal relationship with God, a message to be proclaimed in the world.

She understands the initiation into the sacrament of matrimony as "preparation for marriage in the process of Christian initiation, emphasising the link between marriage, baptism and the other sacraments" (Pope Francis, 2016, 206). Such reflection merely triggers a discussion of proposed subject.
\end{abstract}

Keywords: initiation into sacrament, kerygma, preparation for marriage 


\section{Wprowadzenie}

Podejmowanie ważnych przedsięwzięć wymaga przygotowania. Przygotowujemy się do matury, poprzez studia do wykonywania wymarzonego zawodu, ale także należy dobrze przygotować się do realizacji powołania życiowego, w tym do małżeństwa. I nie mam tu na myśli stroju, sali, gości czy menu, ale przygotowanie wewnętrzne nacechowane dojrzałością w sferze cielesnej, psychicznej, moralnej, duchowej, społecznej i religijnej.

Małżeństwo jest najpowszechniejszą formą realizowania powołania. Wielu młodych ludzi na progu swojej dorosłości wybiera małżeństwo i rodzinę jako drogę urzeczywistniania powołania do miłości. Zbudowanie szczęśliwego małżeństwa i trwałej rodziny jest trudnym zadaniem, dlatego wymaga dojrzałości i odpowiedniego przygotowania. Winno być ono podjęte w rodzinie przez przykład życia, hierarchię wartości, naukę cnót takich jak np. odpowiedzialność, pracowitość czy wierność, ale także przez Kościół i katechezę przedmałżeńską, katechezę parafialną czy kursy dla narzeczonych.

5 października 2014 r. odbyło się III nadzwyczajne zgromadzenie ogólne Synodu Biskupów nt. „Wyzwań duszpasterskich dla rodziny w kontekście nowej ewangelizacji”, natomiast 24 października 2015 roku został wydany dokument „Misja i powołanie rodziny w Kościele i w świecie wspótczesnym". Te dwa wydarzenia skłaniają do refleksji nad przygotowaniem do małżeństwa.

\section{Przygotowanie do małżeństwa}

Współczesny świat, a w nim człowiek przeżywa kryzys psychiczny, moralny i religijny. Objawy procesu dezintegracji dostrzegalne w dzisiejszym świecie wydają się być następujące: rozkład norm moralnych, bezcelowość w życiu osobistym, brak szacunku dla wartości i ideałów, nieuznawanie żadnej hierarchii wartości, dyscypliny, intelektualnej tradycji społecznej i religijnej, poczucie nudy czy absurdalności życia, przewaga sił utrudniających zjednoczenie świata, nacjonalizm, militaryzm, kryzys wiary religijnej (Spengler, 2010). Dostrzegając ilość trudności Ch. Dowson twierdzi, że nie ma innej możliwości odrodzenia świata jak tylko poprzez etykę i religię, poprzez realizację miłości bliźniego, przez uduchowienie jednostek i społeczeństw, poprzez wskrzeszenie świadomości metafizycznej, kierowanie człowieka ku wyższym wartościom duchowym, transcendentnym, poprzez uprawianie ascezy moralnej i naukowej, poszukiwanie prawdziwej mądrości, poprzez odrodzenie religii (Łukasik, 2000).

Konieczna jest zatem odpowiednia formacja rozumiana jako trwały wpływ jednej osoby na drugą w celu ukształtowania w nim pewnych struktur poznawczo-oceniajacych, 
systemu wartości czy wytworzenia wypływających z nich działań w określonym kierunku (Chlewiński, 1989, kol. 389).

Miejscem formacji religijnej, duchowej jest parafia, która pełni funkcje przepowiadania, sprawowania kultu, służbę miłości i funkcję misyjną. Jak wskazuje Kodeks Prawa Kanonicznego chodzi o ewangelizację wewnętrzną, skierowaną na własne środowisko i zewnętrzną, obejmującą cały świat (KPK, kan. 160). W związku z tym, „przepowiadanie, powinno otworzyć drogę formacji i dojrzewania” (Franciszek, 2013, nr 160). Szczególnej dojrzałości wymaga podjęcie decyzji życiowej, w tym decyzji dotyczącej małżeństwa. Dziś „bardziej niż kiedykolwiek, w naszych czasach konieczne jest przygotowanie młodych do małżeństwa i życia rodzinnego. Dlatego Kościół winien popierać lepsze i intensywniejsze programy przygotowania do małżeństwa, ażeby wyeliminować [...] trudności, z którymi boryka się tyle małżeństw, a bardziej jeszcze po to, aby stworzyć pozytywne warunki powstawania i dojrzewania udanych małżeństw"(Jan Paweł II, 2000, nr 66).

Ponieważ to właśnie parafia jest właściwym miejscem katechizowania i doprowadzenia do pełni życia chrześcijańskiego, winna być przede wszystkim miejscem dla katechezy przedmałżeńskiej w trakcie której podejmowane zostaną zagadnienia związane z teologią małżeństwa i rodziny, problematyką zagrożeń i obroną rodziny, nauką naturalnych metod rozpoznawania płodności $\mathrm{w}$ kontekście świętości życia i odpowiedzialności za przyszłe losy społeczeństwa (Dyrektorium Duszpasterstwa Rodzin, 2003, s. 26), wzajemnego odniesienia mężczyzny i kobiety.

Priorytetowym jednak celem katechezy przedmałżeńskiej powinno być nie tyle przekazanie pewnych informacji, co wykształcenie postaw życia chrześcijańskiego, zgłębianie swojej wiary, odkrywanie relacji z Bogiem, która pozwoli trwale wejść w rzeczywistość małżeństwa i rodziny (Pietruszka, Parzyszek, 2019, s. 56). W czasie bliższego przygotowania młodzi ludzie powinni dokonać analizy, na ile ich życie jest dojrzałe i skonfrontować je z osobistym życiem wiary. Ten czas pozwala spojrzeć na siebie wzajemnie pod względem duchowym, zastanowić się, jak ma wyglądać życie sakramentalne we dwoje (Trujillo, 2010, s. 191).

Oprócz aspektów religijnych katecheza ma za zadanie przekazać wiedzę na temat różnic psychicznych u kobiety i mężczyzny, wiedzę o potrzebach i ich zaspokajaniu, aby związek mógł właściwie funkcjonować, i o pojawiających się konfliktach oraz ich rozwiązywaniu we wspólnym życiu. Istotne do poruszenia są elementy dotyczące kierowania się wyborem partnera i przybliżenie konsekwencji niewłaściwego doboru współmałżonka. Niezwykle ważne jest również odniesienie do kwestii płciowości, czystości przedmałżeńskiej czy wierności (Cudak, 1999, s. 148n). Zauważyć w nich można odniesienie do roli wspólnoty w życiu człowieka, kwestie różnych dróg powołania życiowego 
(małżeństwo, kapłaństwo, życie zakonne, życie samotne), informacje na temat budowania więzi w relacjach, aż w końcu konkretne odniesienia do sakramentu małżeństwa.

Chodzi o to, aby pobudzić narzeczonych „i pomagać im, aby mogli wyrazić to, czego każdy oczekuje od ewentualnego małżeństwa, swego sposobu rozumienia, czym jest miłość i zaangażowanie, czego każdy z nich pragnie od drugiej osoby, jaki typ wspólnego życia chce planować" (Franciszek, 2016a, nr 209).

Mając na względzie dobro narzeczonych, należy stworzyć im odpowiedni kontekst wiary „w którym będzie celebrowane i przeżywane małżeństwo. Ten decydujący dla trwałości i prawdy sakramentu małżeństwa aspekt wymaga od proboszczów, by byli coraz bardziej świadomi delikatnego zadania, jakie jest im powierzone $\mathrm{w}$ kierowaniu procesem przygotowania do sakramentu małżeństwa przyszłych małżonków i doprowadzeniu do tego, aby była w nich widoczna i rzeczywista synergia między foedus i fides. Chodzi o to, aby od wizji czysto prawnej i formalnej przygotowania przyszłych małżonków przejść do osadzenia $\mathrm{w}$ sakramencie $a b$ initio, to znaczy poczynając od drogi ku pełni ich foedus przymierza, podniesionego przez Chrystusa do rangi sakramentu" (Franciszek, 2017, s. 1112).

Kolejnym zadaniem jest pomóc młodym małżonkom w postępowaniu drogą wiary. W związku z tym, „potrzebne jest wypracowanie, odważnie i kreatywnie, programu formacji dla młodych małżonków, $\mathrm{z}$ inicjatywami mającymi na celu pogłębianie świadomości przyjętego sakramentu. Chodzi o to, by zachęcać ich do rozważania rozmaitych aspektów ich codziennego życia małżeńskiego, które jest znakiem i narzędziem miłości Bożej, wcielonej w historię ludzi. (...). Wspólnota chrześcijańska winna przyjmować młode pary małżeńskie, towarzyszyć im i pomagać, stwarzając odpowiednie okazje i dostarczając narzędzia - poczynając od uczestnictwa w niedzielnej Mszy św. - aby pielęgnować życie duchowe zarówno w obrębie życia rodzinnego, jak i w ramach programu duszpasterskiego $\mathrm{w}$ parafii czy $\mathrm{w}$ stowarzyszeniach. (...). Jest rzeczą pożądaną, aby na drodze rozwoju ludzkiego i duchowego młodych małżonków były odpowiednie grupy, w których można przechodzić proces stałej formacji: poprzez słuchanie Słowa, konfrontowanie się w kwestiach dotyczących życia rodzin, modlitwę, braterskie dzielenie się" (Franciszek, 2017).

W tym miejscu warto jest jeszcze zwrócić uwagę na cztery postawy, które powinny charakteryzować każdą działalność Kościoła, a więc także tę skierowaną do osób przygotowujących się do zawarcia małżeństwa sakramentalnego: przyjąć, towarzyszyć, rozeznawać i integrować.

Przyjąć, czyli dotrzeć do każdego człowieka z czułością. Dotrzeć do serca i umysłu z miłosierdziem (Franciszek, 2016a, nr 310) dając świadectwo życia Ewangelią, bez dystansu w stosunku do drugiego człowieka i jego udręk, tak, aby rzeczywiście wejść w kontakt z konkretnym człowiekiem i jego historią (Franciszek, 2016a, nr 308). 
Towarzyszyć, czyli kroczyć razem, aby „towarzyszyć możliwym etapom wzrastania osób formujących się dzień po dniu" (Franciszek, 2013, nr 44). Pomóc w pracy nad wewnętrznymi mechanizmami na poziomie zmysłów, doznań, emocji, uczuć, pragnień czy namiętności.

Rozeznawać, inaczej rozpoznawać drogi życia człowieka w znaczeniu pastoralnym, ewangelicznym i duchowym bez wykluczania wiedzy psychologicznej, socjologicznej czy moralnej w celu odczytania sensu życia człowieka wobec Boga. W Adhortacji apostolskiej "Gaudete et exsultate" o powołaniu do świętości w świecie współczesnym, papież Franciszek nazywa rozeznanie narzędziem „walki, do lepszego podążania za Panem. Jest nam potrzebne zawsze: abyśmy byli zdolni do rozpoznawania czasów Boga i Jego łaski, abyśmy nie marnowali natchnień Pana, aby nie odrzucać Jego zachęty do rozwoju. Często dokonuje się to w małych rzeczach, w tym, co wydaje się nieistotne (...). Chodzi o to, aby nie stawiać granic temu, co wielkie, co lepsze i najpiękniejsze, ale jednocześnie skupiać się na tym, co małe, na codziennym zaangażowaniu" (Franciszek, 2018, nr 169).

Ostatnią postawą do przyjęcia której zachęca papież Franciszek jest integracja rozumiana w sposób szeroki jako integracja z samym sobą i ze wspólnotą Kościoła, która pozwala na duchowy rozwój, dojrzewanie i wzrost miłości. Ona stanowi cel rozeznawania i towarzyszenia (Franciszek, 2016a, nr 299).

Odnosząc się do wskazań papieża Franciszka, Konferencja Episkopatu Polski wydała dokument zatytułowany "Wytyczne pastoralne do adhortacji Amoris laetitia, zatwierdzone 08.06.2018 roku" wskazując w nim na nowe impulsy w posłudze duszpasterskiej narzeczonych. Czytamy, że „trzeba pomóc młodym ludziom w odkryciu wartości i bogactwa małżeństwa. Trzeba przypomnieć o znaczeniu cnót, zwłaszcza czystości, która jest warunkiem autentycznego rozwoju oblubieńczej miłości. Zarówno przygotowanie bliższe, jak i towarzyszenie bezpośrednie powinny przekonać narzeczonych, aby nie postrzegali pobrania się jako końca drogi i aby podjęli małżeństwo jako powołanie, które wymaga stanowczej i realistycznej decyzji, aby wspólnie przejść przez wszystkie próby i trudne chwile" (a, 2016, nr 211). Niezwykle ważne wydają się być dobierane treści wraz z odnowionym przepowiadaniem kerygmy, „które przekazywane w sposób atrakcyjny i przyjazny pomogą im zaangażować się w proces trwający całe życie z wielkodusznością i wolnością. Jest to rodzaj »inicjacji« do sakramentu małżeństwa, który zapewni im niezbędne elementy, aby mogli go przyjąć z najlepszą dyspozycją i rozpocząć życie rodzinne z pewną solidnością" (Franciszek, 2016a, nr 207). Każdy Kościół lokalny winien rozeznać, która z form bezpośredniego przygotowania do małżeństwa jest najlepsza i zadbać o formację, która nie zniechęci młodych do sakramentu" (Wytyczne pastoralne do adhortacji Amoris laetitia, zatwierdzone 08.06.2018 roku, nr 3).

Już wcześniej papież Jan Paweł II, w adhortacji apostolskiej o zadaniach rodziny chrześcijańskiej Familiaris consortio apelował, aby Konferencje Episkopatów, które są 
zainteresowane właściwymi inicjatywami zmierzającymi do ułatwienia przyszłym małżonkom pełnego uświadomienia wagi ich własnej decyzji, a duszpasterzom stwierdzenia u nich odpowiedniej dyspozycji, postarały się o wydanie Dyrektorium Duszpasterstwa Rodzin. To Dyrektorium powinno przede wszystkim ustalić zakres tematów, czas trwania i metody "kursów przygotowawczych”, z zachowaniem równowagi między różnymi aspektami - doktrynalnym, pedagogicznym, prawnym i medycznym - dotyczącymi małżeństwa i taką nadać im strukturę, ażeby przygotowujący się do małżeństwa obok pogłębienia intelektualnego, poczuli się zachęceni o żywego włączenia się we wspólnotę kościelną" (Jan Paweł II, 2000, 66).

Podczas 322 Zebrania Plenarnego Konferencji Episkopatu Polski w Warszawie w dniu 1 maja 2003 roku został przyjęty dokument zatytułowany "Dyrektorium Duszpasterstwa Rodzin" podejmujący m.in. zagadnienia dotyczące przygotowanie do małżeństwa i do życia w rodzinie. W obecnym wydaniu, Dyrektorium ,jest kontynuacją troski Kościoła w Polsce o małżeństwa i rodziny, podejmowanej od kilkudziesięciu lat. Skupiała się ona w pracach Komisji Episkopatu Polski do Spraw Rodzin, która od roku 1996 przekształciła się w Radę Episkopatu Polski do Spraw Rodzin" (Dyrektorium Duszpasterstwa Rodzin, 2003, s. 10).

Przywołane Dyrektorium powstało w oparciu o następujące dokumenty:

- Pierwszą Instrukcję Episkopatu Polski dla duchowieństwa o przygotowaniu wiernych do sakramentu małżeństwa i o duszpasterstwie rodzin z 12 lutego 1969;

- Drugą Instrukcję Episkopatu Polski dotyczącą przygotowania do małżeństwa i życia rodzinnego oraz wprowadzenia nowego obrzędu sakramentu małżeństwa z 12 marca 1975;

- Instrukcję Episkopatu Polski o przygotowaniu do zawarcia małżeństwa w kościele katolickim z 5 września 1986 (zatwierdzona przez Stolicę Apostolską 17 stycznia 1987);

- Instrukcję Episkopatu Polski w sprawie duszpasterstwa małżeństw o różnej przynależności kościelnej z 11 marca 1987;

- Instrukcję Papieskiej Rady do Spraw Rodziny: Przygotowanie do sakramentu Małżeństwa z 13.05.1996.

Ponadto Dyrektorium nawiązuje w swojej treści do dokumentów powszechnych Kościoła, są to m.in. dokumenty Soboru Watykańskiego II: Konstytucja dogmatyczna o Kościele Lumen gentium (1964), Konstytucja duszpasterska o Kościele w świecie współczesnym Gaudium et spes (1965), encyklika papieża Pawła VI Humanae Vitae (1968), adhortacja apostolska Familiaris consortio (1981), encyklika papieża Jana Pawła II Evangelium vitae (1995), Karta Praw Rodziny (1983), List do Rodzin Ojca św. Jana Pawła II (1994) oraz Instrukcja Papieskiej Rady ds. Rodziny Przygotowanie do sakramentu Małżeństwa (1996). 
Dzisiaj znowu potrzeba refleksji związanej z tak ważnym zagadnieniem jakim jest przygotowanie do sakramentu małżeństwa. Dopełniając treści już zastane, oraz kreśląc nowe programy, papież Franciszek zaprasza do realizacji wspólnego projektu pt. „Małżeństwo" wskazując na przepowiadanie kerygmatu i inicjację w sakrament.

\section{Głoszenie kerygmatu}

Słowo „kerygmat" pochodzi z języka greckiego i oznacza: obwieszczenie, proklamację, orędzie, ważną wiadomość a także rozkaz (Paciorek, 2000, kol. 1360-1362). W nauczaniu papieża Franciszka jest on „ogniem Ducha, udzielającego się pod postacią języków i sprawiającego, że wierzymy w Jezusa Chrystusa, który przez swą śmierć i zmartwychwstanie objawia nam i komunikuje nieskończone miłosierdzie Ojca" (Franciszek, 2013, nr 164). Jest orędziem mającym moc przemiany życia, prowadzącym do osobowej relacji z Bogiem, zawiera także konieczność proklamowania go w świecie. Jest to najbardziej potrzebne orędzie, wręcz pożądane (także, nr 35), aby ludzie mogli spotkać i doświadczyć Boga. „Jeśli nawiążesz z Nim przyjaźń i zaczniesz rozmawiać z żywym Chrystusem o konkretnych sprawach twojego życia, to będzie wspaniałe doświadczenie, będzie to doświadczenie podstawowe, które będzie wspierało twoje życie chrześcijańskie. Jest to również doświadczenie, które możesz przekazać innym ludziom" (Franciszek, 2019, nr 129).

Kerygmat, to wreszcie „wieść zawierająca trzy wielkie prawdy, które wszyscy musimy wielokrotnie usłyszeć” (tamże, nr 111). Odnoszą się one do przyjęcia przesłania, że Bóg kocha człowieka, Chrystus go zbawia i że On żyje (Zborowski, 2019, s. 263). Takie rozumienie kerygmatu odczytać możemy w adhortacji Christus vivit.

Bóg jest tym, który pierwszy umiłował człowieka, a jego miłość „nie przytłacza, nie marginalizuje ani nie ucisza i nie milczy, miłość, która nie upokarza ani nie zniewala. Jest to miłość Pana, miłość codzienna, dyskretna i respektująca, miłość wolności i dla wolności, miłość, która leczy i uwzniośla. To miłość Pana, która wie więcej o powstawaniu niż upadkach, o pojednaniu niż zakazach, o dawaniu nowej szansy niż potępieniu, o przyszłości niż przeszłości" (Franciszek, 2019, s. 19).

Najpełniejszym wyrazem miłości Boga do człowieka, jest śmierć Jezusa Chrystusa poniesiona na krzyżu. Jedynie co ten musi zrobić, to pozwolić się zbawić, bez zapłaty, za darmo. A ci, którzy pozwolą się zbawić, „zostają wyzwoleni od grzechu, od smutku, od wewnętrznej pustki, od izolacji” (Franciszek, 2013, nr 1). „Bo tylko to, co jest kochane, może być zbawione. Tylko to, co się akceptuje, może zostać przemienione. Miłość Pana jest większa niż wszystkie nasze sprzeczności, wszystkie nasze słabości i wszystkie nasze małoduszności. Ale właśnie poprzez nasze sprzeczności, słabości i małoduszności chce On napisać tę historię miłości" (Franciszek, 2019, s. 27). 
Trzecią prawdą nakreśloną przez papieża Franciszka, jest stwierdzenie, że Jezus żyje i to trzeba nieustannie przypominać, „ponieważ grozi nam, że będziemy przyjmowali Jezusa Chrystusa tylko jako dobry przykład z przeszłości, jako wspomnienie, jako kogoś, kto nas zbawił dwa tysiące lat temu” (Franciszek, 2019, 125). A jeśli „On żyje, to naprawdę może być obecny w twoim życiu, w każdej chwili, aby napełnić je światłem. Tak więc nigdy nie będzie więcej samotności ani opuszczenia" (tamże).

Zatem kerygmat to takie orędzie, które jest najważniejsze i najbardziej potrzebne. Jako takie, powinno zajmować centralne miejsce w działalności ewangelizacyjnej, albowiem nie ma nic bardziej solidnego, głębokiego, pewnego, treściwego i mądrego niż kerygmat (Franciszek, 2016a, nr 58).

W oparciu o kerygmat można budować życie jako na solidnym fundamencie, który pozwala odkryć swoje powołanie oraz pomóc w ukształtowaniu mentalności chrześcijanina, czyli odkupionego dziecka Bożego, która staje się całożyciowym przekonaniem i stylem postępowania (Franciszek, 2019, nr 212-215).

Jeśli kerygmat jest piękny, ważny, większy, bardziej pociągający, najbardziej potrzebny, solidny, głęboki, pewny, treściwy, mądry, to bez wątpienia jest rzeczywistością, która nigdy nie może zostać przemilczana (tamże, nr 111).

\section{Proponowanie inicjacji w sakrament}

Katechizm Kościoła Katolickiego naucza, że „sakramenty są skutecznymi znakami łaski, ustanowionymi przez Chrystusa i powierzonymi Kościołowi. Przez te znaki jest nam udzielane życie Boże. Obrzędy widzialne, w których celebruje się sakramenty, oznaczają i urzeczywistniają łaski właściwe każdemu sakramentowi. Przynoszą one owoc w tych, którzy je przyjmują z odpowiednią dyspozycją" (KKK 1131). Tak więc, sakrament by oddziaływał mocą zawartej $\mathrm{w}$ nim łaski, potrzebuje przemiany życia, osobowej relacji z Bogiem, a także świadectwa.

W adhortacji apostolskiej Amoris laetitia Papież Franciszek wskazuje, że istnieje konieczność „zakorzenienia przygotowania do małżeństwa w procesie inicjacji chrześcijańskiej, z zaakcentowaniem powiązania małżeństwa ze chrztem oraz innymi sakramentami" (Franciszek, 2016a, nr 206) w celu uświadomienia młodym ludziom sakramentalnego wymiaru życia chrześcijańskiego oznaczającego, że każdy chrześcijanin przyjmujący sakramenty, zostaje włączony w historię zbawienia, życie Jezusa i życie Kościoła, a przez to jego egzystencja ma wymiar historiozbawczy, chrystologiczny i eklezjalny. W związku z tym, "priorytetowo należy potraktować - wraz z odnowionym przepowiadaniem kerygmy - te treści, które przekazywane w sposób atrakcyjny i przyjazny pomogą im zaangażować się w proces trwający całe życie „z wielkodusznością i wolnością". Jest to rodzaj „inicjacji” do sakramentu małżeństwa, który zapewni im niezbędne elementy, 
aby mogli go przyjąć z najlepszą dyspozycją i rozpocząć życie rodzinne z pewną solidnością" (Franciszek, 2016a, nr 207).

Przemawiając do trybunału Roty Rzymskiej, papież Franciszek przypomniał konieczność «nowego katechumenatu» w przygotowaniu do małżeństwa oraz pilnie wprowadzenie tego, co zaproponował wcześniej papież Jan Paweł II w adhortacji apostolskiej Familiaris consortio (przygotowanie dalsze, bliższe i bezpośrednie). „Chodzi o to, żeby jak przy chrzcie dorosłych katechumenat należy do procesu sakramentalnego, tak również przygotowanie do małżeństwa stało się integralną częścią całej sakramentalnej procedury małżeństwa jako antidotum, które zapobiega mnożeniu się związków zawieranych nieważnie czy nietrwałych". (Franciszek, 2017).

Doceniając wkład i zaangażowanie wielu duszpasterzy oraz wspólnot chrześcijańskich papież przypomina, że „istnieje wiele uprawnionych sposobów organizowania bezpośredniego przygotowania do małżeństwa, a każdy kościół lokalny rozezna, który z nich jest najlepszy zapewniając odpowiednią formację" (Franciszek, 2016, nr 207). Docenia użyteczność tworzenia odpowiednich grup narzeczonych, proponowanie konferencji, wydarzenia zindywidualizowane mające na celu „pomoc każdemu, aby nauczył się kochać tę konkretną osobę, z którą pragnie dzielić życie" (Franciszek, 2016a, nr 208).

\section{Zakończenie}

Powyżej przedstawiona problematyka przygotowania do małżeństwa ze zwróceniem szczególnej uwagi na głoszenie kerymatu i inicjację w sakrament, wydaje się być rzeczowym uzasadnieniem potrzeby dostrzegania konieczności zajęcia się zagadnieniem, a ponadto potrzeby angażowania się wszystkich, którzy pracują dla dobra małżeństwa i rodziny tj. pedagogów, psychologów, terapeutów, formatorów, teologów czy duszpasterzy.

Dla wszystkich, którzy widzą potrzebę zaangażowania się w proces przygotowania młodych ludzi do małżeństwa ważne jest, aby rozumieli, że wypływa ona z troski o szczęście wszystkich jej członków.

Mając na uwadze fakt, że rodzina stanowi istotny czynnik życia indywidualnego i społecznego, należy zgodzić się z tym, że jej funkcja społeczna rozpoczyna się od najwcześniejszego okresu życia i rozgrywa się w wielu sferach jednocześnie: w sferze biologiczno-popędowej (opieka, pomoc materialna, kształtowanie więzi biologicznych i gospodarczych); w sferze psychiczno-uczuciowej (oddziaływanie na psychikę dziecka, powstawanie i umacnianie się więzi emocjonalnych, możliwość uzewnętrznienia potrzeb uczuciowych, nauka ofiarności i bezinteresowności); w sferze społeczno-kulturowej (umożliwianie przystosowania się do życia w innych grupach, nauka kompromisu, przekazywanie dziedzictwa kulturowego i wzorów); w sferze świadomościowo-moralnej 
(przekazywanie i internalizacja norm, systemu wartości, dostarczanie modeli zachowań moralnych (Adamski, 1981, s. 366-368).

W tym znaczeniu wydaje się być właściwym stwierdzenie, że należy dołożyć wszelkich starań, aby należycie pomóc młodym ludziom przygotować się do małżeństwa po to, aby ich małżeństwo i rodzina były trwałe, aby były szkołami miłości bowiem środowisko rodzinne, w którym człowiek uzyskuje odpowiednie warunki dla właściwego rozwoju osobowości, a więc i kochania jest jedną z najcenniejszych wartości.

\section{Bibliografia:}

Adamski, F. (1981). Znaczenie wychowania w rodzinie dla rozwoju osobowego dziecka, (w:) F. Adamski (red.), Miłość, małżeństwo, rodzina, 366-369, Kraków: WAM.

Cattaneo, A. (2017). Przygotować się do matżeństwa pod kierunkiem papieża Franciszka, Kraków: Wydawnictwo św. Stanisława BM.

Chlewiński, Z. (1989). Formacja, (w:) L. Bieńkowski, P. Hemperek, S. Kamiński, J. Misiurek, K. Stawecka, A. Stępień, A. Szafrański, J. Szlaga, A. Weiss (red.), Encyklopedia Katolicka, t. V, kol. 389, Lublin: Towarzystwo Naukowe Katolickiego Uniwersytetu Lubelskiego.

Cudak, H. (1999). Od rodziny pochodzenia do rodziny prokreacji, Łowicz: Mazowiecka Wyższa Szkoła Humanistyczno-Pedagogiczna.

Dyrektorium Duszpasterstwa Rodzin (2003). Warszawa: Fundacja Vita Familiae.

Franciszek, (2013). Adhortacja apostolska Evangelii gaudium do biskupów, prezbiterów i diakonów, do osób konsekrowanych, do wiernych świeckich o głoszeniu ewangelii we wspótczesnym świecie, Kraków: Wydawnictwo M.

Franciszek, (2016a). Posynodalna Adhortacja apostolska Amoris laetitia. O mitości w rodzinie, Kraków: Wydawnictwo M.

Franciszek, (2016b). Rodzina uratuje świat, Gliwice: Wydawnictwo Fundacja Instytut Globalizacji.

Franciszek, (2017a). Papież do trybunału Roty Rzymskiej: wiara a małżeństwo, https://opoka.news/aktualnosci/1803, (dostęp: 15.12.2020).

Franciszek, (2017b). Przemówienie do członków Trybunału Roty Rzymskiej (21.01.2017), L'Osservatore Romano, Wyd. polskie, 2 (390), 9-12.

Franciszek, (2018). Adhortacja apostolska Gaudete et exsultate. O powołaniu do świętości w świecie wspótczesnym, Wrocław: TUM.

Franciszek, (2019). Posynodalna adhortacja apostolska Christus vivit do młodych i całego Ludu Bożego, Poznań: Pallottinum.

Franciszek, (2019). Przemówienie podczas ceremonii powitania i otwarcia Światowego Dnia Młodzieży w Panamie na Campo Santa Maria la Antigua - Cinta Costera (24 stycznia 2019), L'Osservatore Romano, wyd. polskie, 2 (410), 17-21. 
Franciszek, (2019). Przemówienie podczas czuwania z młodymi w ramach XXXIV Światowego Dnia Młodzieży w Panamie (26 stycznia 2019), L'Osservatore Romano, wyd. polskie, 2 (410), 26-31.

Jan Paweł II, (2000). Adhortacja apostolska Familiaris consortio, o zadaniach rodziny chrześcijańskiej w świecie wspótczesnym, Wrocław: TUM.

Katechizm Kościoła Katolickiego, (1994). Poznań: Pallottinum.

Kodeks Prawa Kanonicznego, (2008), Poznań: Pallottinum.

Łukasik, I. (2010). Wkład chrześcijaństwa w kulturę wedtug Christophera Dawsona, Lublin: Towarzystwo Naukowe Katolickiego Uniwersytetu Lubelskiego Jana Pawła II.

Pietruszka, L., Parzyszek, M. (2019). Narzeczeństwo - droga która warto przejść, Lublin: Wydawnictwo TN KUL.

Spengler, O. (2001). Zmierzch Zachodu, Warszawa: Aletheia.

Trujillo, A.L. (2010). Przygotowanie do sakramentu małżeństwa (w:) M. Brzeziński (red.), W trosce o dobro małżeństwa i rodziny. Dokumenty Papieskiej Rady ds. Rodziny, 175-205, Lublin: Wydawnictwo KUL.

Wytyczne pastoralne do adhortacji Amoris laetitia, zatwierdzone 8.06.2018, za: https://opoka.org.pl/biblioteka/W/WE/kep/wytyczne_amoris_08062018.html, (dostęp: 30.12.2020).

Zborowski, M. (2019). Kerygmat w ujęciu papieża Franciszka. Refleksje dogmatycznopastoralne, Teologia w Polsce, 2 (13), 261-280. 